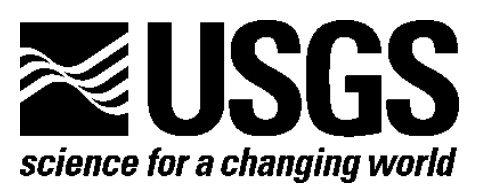

\title{
Deposit Model for Closed-Basin Potash-Bearing Brines
}

By Greta J. Orris

Open-File Report 2011-1283

\author{
U.S. Department of the Interior
}

U.S. Geological Survey 


\section{U.S. Department of the Interior \\ KEN SALAZAR, Secretary}

\section{U.S. Geological Survey \\ Marcia K. McNutt, Director}

U.S. Geological Survey, Reston, Virginia: 2011

For more information on the USGS—-the Federal source for science about the Earth, its natural and living resources, natural hazards, and the environment-visit http://www.usgs.gov or call 1-888-ASK-USGS

For an overview of USGS information products, including maps, imagery, and publications, visit $h t t p: / / w w w . u s g s . g o v / p u b p r o d$

To order this and other USGS information products, visit $h$ ttp://store.usgs.gov

Suggested citation:

Orris, G.J., 2011, Deposit model for closed-basin potash-bearing brines: U.S. Geological Survey Open-File Report 2011-1283,11 p.

Any use of trade, product, or firm names is for descriptive purposes only and does not imply endorsement by the U.S. Government.

Although this report is in the public domain, permission must be secured from the individual copyright owners to reproduce any copyrighted material contained within this report. 


\section{Contents}

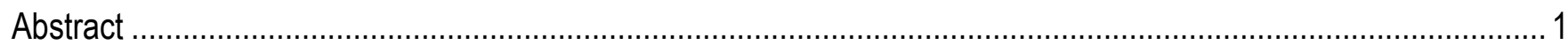

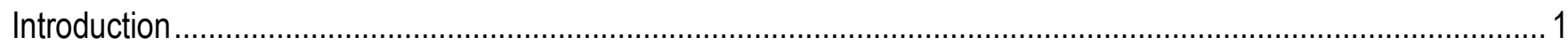

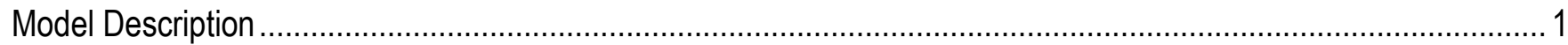

Geology ………

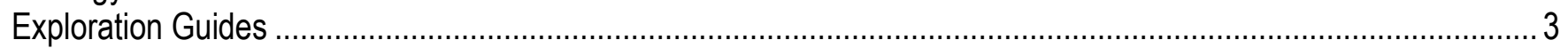

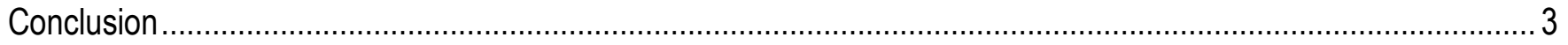

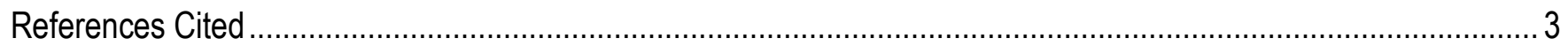

\section{Figures}

Figure 1. Distribution of closed-basin potash-bearing brine deposits listed in table 1; deposits are shown as green squares.

Figure 2. Possible extent of area underlain by Lake Bonneville potash-bearing brines, including the Great Salt Lake, the Great Salt Lake Desert, and Sevier Lake. The extent of Lake Bonneville was determined by using the Digital Elevation Model data, and everything above 5090 feet is excluded. This is a good match with the map shown in Currey and others, 1984.

Figure 3. Sketch map of Qaidam Basin, China, showing playas and salt lakes. The Qarhan Salt Plain (playa), where most of the current production occurs, is shown in the lower center of the figure.

\section{Table}

Table 1. Known potash-bearing brine deposits in continental closed basins. For size comparison purposes, a 1 billion metric ton stratabound potash deposit on average would contain less than 250 Mt of $\mathrm{K}_{2} \mathrm{O}(400 \mathrm{Mt} \mathrm{KCl}, 210 \mathrm{Mt} \mathrm{K})$..... 


\title{
Deposit Model for Closed-Basin Potash-Bearing Brines
}

\author{
By G.J. Orris
}

\begin{abstract}
Closed-basin potash-bearing brines are one of the types of potash deposits that are a source of potash production within the United States, as well as other countries. Though these deposits are of highly variable size, they are important sources of potash on a regional basis. In addition, these deposits have a high potential of co- and by-product production of one or more commodities such as lithium, boron, magnesium, and others.
\end{abstract}

\section{Introduction}

Current global production and resources of potash are dominated by stratabound potash-bearing salt deposits. However, in some areas of the world, closed-basin potash-bearing brines are the main source for production of potash and potash-bearing brine resources (table 1). Closed-basin potashbearing brines exist in many parts of the world, including the United States. Although typically smaller than stratabound potash deposits, potash-bearing brine deposits have the potential to contain significant economic contents of potash (table 1) and other commodities; these commodities include salt (halite), boron, lithium, and (or) magnesium, and may include other commodities. During the potash-exploration boom of the past few years, multiple new resources have been identified (table 1). Current or past production of potash from this deposit type has been reported in Chile, China, Israel, Jordan, Libya, Uganda, and the United States. In the United States, potash is produced from brines of the Great Salt Lake and at Wendover in Utah and has been produced in the past from Searles Lake brines in California.

Potash denotes a variety of mined and manufactured salts, all of which contain the element potassium in water-soluble form (Jasinski, 2011). The term is used by industry to refer to potassium chloride, as well as potassium sulfate, nitrate, and oxide (Neuendorf and others, 2005). For the purposes of this model, potash refers to potassium ores and minerals, including potassium-bearing brines.

\section{Model Description}

The general deposit model provides a descriptive basis for the identification and assessment of closed-basin potash-bearing brine deposits of a type and style similar to those found in the Great Salt Lake in Utah, the Salar de Atacama of Chile, and in the Qaidam Basin of China (fig. 1). The model is intended to provide a basis for assessing the probability of the occurrence of similar deposits using the current U.S. Geological Survey three-part assessment methodology (Singer, 1993; Singer and Menzie, 2010). In addition, the model will aid in the identification of continental closed basins where brines containing potentially economic contents of potassium are most likely to occur.

Closed-basin potash-bearing brine deposits typically contain the potential for extraction of multiple commodities including potash, lithium, boron, magnesium, and salt, and may include sodium sulfate, sodium carbonate, or sulfur. The importance of an individual commodity, such as potash, varies 
with local geology, with current and perceived future economic conditions, and with regional need for that commodity. The geology within the drainage basin impacts the chemistry of runoff and spring waters and the resulting brine and thus controls not only which constituents may be concentrated in the brines, but the relative amounts of the constituents and the ease with which a given commodity, such as potash, can be extracted. This model highlights the conditions under which potassium might be expected to be a major component of a brine deposit and those features of the deposit most likely to impact development of the brine. Significant papers upon which the closed-basin potash-bearing brine model is based include: Ericksen and Salas (1989), Casas and others (1992), Bryant and others (1994), Garrett (1996), Carmona and others (2000), Duan and Hu (2001), Jones and Deocampo (2003), Jones and others (2009), and Risacher and Fritz (2009).

\section{Geology}

Potash-bearing brines may be alkaline or enriched in chloride, sulfate, or calcium, depending on the geology within the drainage basin and the resultant chemistry of the inflows to the basin. Potashbearing brines form in salt lakes and salars or playas in closed basins in arid environments, where high rates of near-surface evaporation concentrated the brine. The duration of this process can extend from hundreds of years to tens of thousands of years, and in some cases, over a million years. Lake Bonneville existed between 28,000 and 7,000 years ago during a cooler and wetter climate (fig. 2). The potash-bearing brines of the Great Salt Lake and at Wendover, Utah, in the Great Salt Lake Desert are remnants of this lake. These brine-bearing basins are commonly structural basins that formed in volcaniclastic terranes.

The chemical constituents of the water flowing into a potash-bearing basin from precipitation runoff, groundwater, and hydrothermal springs have commonly been scavenged from the local country rocks. Source rocks of the constituents are most commonly acidic to intermediate volcanic rocks, but also include older saline rocks and continental sedimentary rocks (Alonso and Risacher, 1996; Risacher and Fritz, 2009). Sources of potassium in these rocks are weathered minerals, such as orthoclase, microcline, biotite, leucite, and nepheline. Studies have found a positive correlation between potassium, lithium, and boron in brines (Zheng, 1984; Orris, 1997; Carmona and others, 2000), which is probably indicative of their common origin in volcaniclastic terranes that typically are associated with convergent plate boundaries (Orris, 1997). Elevated levels of magnesium are also typical of many of the closedbasin brines.

In addition to the potash-bearing brines, most of these basins have some surface or near-surface evaporites and salts. In some areas, such as the Qaidam Basin in China and the Chott el Djerid in Tunisia, extensive areas of potash minerals may be found (Casas and others, 1992; Bryant and others, 1994). Duan and Hu (2001) reported that potash salt mineralization in the Qarhan playa in China ranges from disseminated potash minerals to stratoid lenses or layered bodies hosted by halite and other evaporites.

Local geologic attributes of potash brine-bearing basins commonly include the presence of Cenozoic continental evaporites. Host rocks may include gypsum and(or) halite, and lacustrine sediments. Associated rocks include volcanic rocks, siltstone, sandstone, and mudstone. The presence of an evaporite-bearing salt lake, salar, or playa may indicate surface or near-surface brines, but the brine may underlie much larger areas that are in part determined by the extent of a pre-existing lake and the porosity and permeability of the host sediments.

Sub-basins may exist within larger basins and have distinctly different characteristics, such as chemistry or grade. These sub-basins may be a result of geologic features, such as faulting in the eastern Tarim Basin, China, in the vicinity of the Luobei sub-basin in which the Lop Nur brine mine is located 
(Wang and others, 2005). In the Great Salt Lake, a railway causeway has led to higher salinities to the north of the man-made feature (Jones and others, 2009).

Sizes of these deposits are highly variable, both in terms of area and the amount of potash contained within the brines. As shown in table 1, the amount of potash can range from a few million metric tons of $\mathrm{K}$ (potassium), $\mathrm{KCl}$ (potassium chloride), or $\mathrm{K}_{2} \mathrm{O}$ (potassium oxide) to over a thousand metric tons. The largest of these deposits have similar potassium contents to some stratabound potash deposits, although they are still significantly smaller than the stratabound deposits of the Elk Point Basin of western Canada. On a regional basis, these deposits may be a significant source of potash. For example, the brine deposits of the Qaidam Basin (fig. 3) are the major source of potash production within China.

\section{Exploration Guides}

The dominant exploration guides for this deposit type include the presence of a salar or playa at the surface, an arid environment, and the presence of continental evaporites or young volcaniclastic sequences. Springs with elevated K (potassium), B (boron), Li (lithium), or Mg (magnesium) contents within the basin may also be indicative of the potential for brine concentration. Elevated $\mathrm{Li}, \mathrm{B}$, or $\mathrm{Mg}$ contents of lacustrine clays may indicate brines at depth. Resistivity logging in boreholes may also be of use in detecting saline brines because of the high conductivity and low resistivity of saline brines; this technique has been used by several of the recent exploration projects, including Salar de Cauchari, where resistivity profiles were constructed as part of the exploration effort (Houston, 2010a). Explorationists should be aware that brine concentrations can vary significantly with seasonal precipitation in some deposits, particularly in near surface deposits, and plan their sampling accordingly.

Environmental concerns that may be associated with this deposit type include subsidence caused by brine withdrawal and issues associated with improper disposal of saline water and materials.

\section{Conclusion}

Closed-basin potash-bearing brine deposits are one of the sources of potash occurring within the United States. Potash production from the Great Salt Lake and at Wendover, Utah is from this deposit type. On a global basis, these deposits are of highly variable size in terms of the amount of contained potash. However, these deposits may be regionally significant producers of potash and offer the potential for the production of other commodities in addition to potash.

\section{References Cited}

Alonso, H., and Risacher, F., 1996, Geoquímica del Salar de Atacama, parte1 — Origen de los componentes y balance salino: Revista Geologica de Chile, v. 23, no. 2, p. 113-122.

Americas Petrogas, 2010, Peru potash and minerals - Growmax agri corp: American Petrogas Web page, accessed March 2, 2010, at http://www.americaspetrogas.com/s/Peru.asp.

Ballivián, Oscar, and Risacher, Francois, 1981, Los salares del Altiplano de Bolivia-Métodos de studio y estimación económica: Paris and La Paz, l'Office de la Recherche Scientifique et Technique Outre-Mer Universidad Mayor de San Andrés, 246 p.

British Sulphur Corporation Limited, 1984, World survey of potash resources (4th ed.): London, UK, British Sulphur Corporation Limited, 145 p.

Bryant, R.G., Sellwood, B.W., Millington, A.C., and Drake, N.A., 1994, Marine-like potash evaporite formation on a continental playa - Case study from Chott el Djerid, southern Tunisia: Sedimentary Geology, v. 90, no. 3-4, p. 269-291. 
Carmona, V., Pueyo, J.J., Taberner, C., Chong, G., and Thirlwall, M., 2000, Solute inputs in the Salar de Atacama (N. Chile): Journal of Geochemical Exploration, v. 69-70, p. 449-452.

Casas, E., Lowenstein, T.K., Spencer, R.J., and Zhang, P., 1992, Carnallite mineralization in the nonmarine, Qaidam Basin, China-Evidence for the early diagenetic origin of potash evaporites: Journal of Sedimentary Petrology, v. 62, no. 5, p. 881-898.

Currey, D.R., Atwood, G., and Mabey, D.R., 1984, Major levels of Great Salt Lake and Lake Bonneville: Salt Lake City, Utah Geological and Mineral Survey Map 73, scale 1:750,000.

Duan, Z., and Hu, W., 2001, The accumulation of potash in a continental basin-The example of the Qarhan Saline Lake, Qaidam Basin, West China: European Journal Mineralogy, v. 13, p. 1223-1233.

Ericksen, G.E., 1963, Geology of the salt deposits and the salt industry of northern Chile: U.S. Geological Survey Open-File Report 63-31, 164 p.

Ericksen, G.E., and Salas O., R., 1989, Geology and resources of salars in the central Andes, in Ericksen, G.E., Cañas Pinochet, M.T., and Reinemund, J.A., eds., Geology of the Andes and its relation to hydrocarbon and mineral resources: Houston, Texas, Circum-Pacific Council for Energy and Mineral Resources, p. 151-164.

Gao, S., Yang, Z., and Huang, S., 1993, Recovery of Na2SO4, $\mathrm{K}_{2} \mathrm{SO}_{4}$, boric acid and lithium salt from Da Chaidan Salt Lake brine, in Kakihana, H., Hardy, H.R., Jr., Hoshi, T., and Toyokura, K., eds., Seventh Symposium on Salt, Volume 1: New York, Elsevier, p. 555-560.

Garrett, D.E., 1996, Potash-Deposits, processing, properties and uses: New York, Chapman \& Hall, $734 \mathrm{p}$.

Geological Survey and Mineral Exploration of Iran, 2007, National geoscience database of Iran: Geological Survey and Mineral Exploration of Iran Web page, accessed February 24, 2007, at http://www.ngdir.ir/MiningInfo/.

Goudarzi, G.H., 1982, Potash in Libya, in Austin, G.S., compiler, Industrial rocks and minerals of the Southwest: New Mexico Bureau of Mines and Mineral Resources Circular 182, p. 27-30.

GrowMax Agri Corp., 2011, Peru, GrowMax Agri Corp.-Potash and minerals: Calgary, Alberta, GrowMax Agri Corp. Web page, accessed May 3, 2011, at http://www.growmaxagricorp.com/contact/contact-information.html.

Gwynn, J.W., 1996, History of potash production from the Salduro salt marsh (Bonneville salt flats), Tooele County: Salt Lake City, Utah Geological Survey Notes, v. 28, no. 2, p. 1-3.

Gwynn, J.W., 2001, The extraction of mineral resources from Great Salt Lake, Utah-History, developmental milestones, and factors influencing salt extraction, in Bon, R.L., Riordan, R.F., Tripp, B.T., and Krukowski, S.T., eds., Proceedings of the 35th Forum on the Geology of Industrial Minerals-The Intermountain West Forum 1999: Salt Lake City, Utah Geological Survey Miscellaneous Publication 01-2, p. 49-61

Hains, D.H., 2011, Technical report on Salar de Maricunga lithium project, northern Chile_-Prepared for Li3 Inc.: Toronto, Ontario, Hains Technology Associates, 105 p.

Houston, J., 2010a, Technical report on the Cauchari project, Jujuy Province, Argentina-NI 43-101 report prepared for Orocobre Ltd.: Milton, Queensland, Orocobre Ltd., 70 p.

Houston, J., 2010b, Technical report on the Salinas Grandes-Guayatayoc project, Jujuy-Salta Provinces, Argentina-Report for NI43-101: Milton, Queensland ,Orocobre Ltd., 80 p.

Houston, J., and Ehren, P., 2010, Technical report on the Olaroz project-NI43-101 report prepared for Orocobre Ltd.: Milton, Queensland, Orocobre Ltd., 119 p.

Industrial Minerals, 2010, GrowMax potash gets \$10m. boost: Industrial Minerals Web page, accessed June 21, 2010, at http://www.indmin.com/Article/2392711/GrowMax-potash-gets-10m-boost.html. 
Jasinski, S.M., 2011, Potash, in Mineral commodity summaries 2011: U.S. Geological Survey, p. 122123. (Also available at http://minerals.usgs.gov/minerals/pubs/commodity/potash/mcs-2011potas.pdf.)

Jones, B.F., and Deocampo, D.M., 2003, Geochemistry of saline lakes, in Drever, J.I., ed., Treatise on geochemistry-Volume 5-Surface and ground water, weathering and soils: Amsterdam, Elsevier Ltd., p. 393-424.

Jones, B.F., Naftz, D.L., Spencer, R.J., and Oviatt, C.G., 2009, Geochemical evolution of Great Salt Lake, Utah, USA: Aquatic Geochemistry, v. 15, no. 1-2, p. 95-121.

Kilic, O., and Kilic, A.M., 2005, Recovery of salt co-products during the salt production from brine: Desalination, v. 186, p. 11-19.

King, Mark, 2010, Amended inferred resource estimation of lithium and potassium at the Cauchari and Olaroz salars, Jujuy Province, Argentina: Halifax, Nova Scotia, Groundwater Insight, 109 p.

Kisitu, V.B., 1991, Fertilizer material occurrences in Uganda: Fertilizer Research, v. 30, p. 187-189.

Larrondo, P., Simon, A., and Etienne, M., 2011, Salar de Diablillos project, Salta Province, Argentina, NI 43-101 Technical Report on brine resource estimate: Santiago, Chile, AMEC International Ingeniería y Construción Limitada, 126 p.

Li3 Energy, 2011, Maricunga overview: Lima, Perú, Li3 Energy Web page, accessed June 13, 2011, at http://www.li3energy.com/projects/maricunga-overview/index.htm.

Mining Exploration News, 2011, Li3 Energy announce executes purchase agreement to acquire Puna Lithium assets in Argentina: Mining Exploration News Web page, accessed August 21, 2011, at http://paguntaka.org/2010/03/25/li3-energy-announce-executes-purchase-agreement-to-acquirepuna-lithium-assets-in-argentina/.

Neuendorf, K.K.E., Mehl, Jr., J.P., and Jackson, J.A., 2005, Glossary of geology (5th ed): Alexandria, Virginia, American Geological Institute, 799 p., accessed online October 5, 2011, at http://www.agiweb.org/pubs/glossary/.

New World Resource Corp., 2008, New World to acquire lithium brine project within the prolific Andean Altiplano: Vancouver, British Columbia, New World Resource Corp. Web page, accessed December 27, 2008, at http://www.newworldresource.com/s/NewsReleases.asp? ReportID $=317797 \&$ Title $=$ New-World-toAcquire-Lithium-Brine-Project-within-the-Prolific-Andean-Altiplano.

Notholt, A.J.G., 1983, Potash in developing countries, in McKercher, R.M., ed., Potash 83-Potash technology-Mining, processing, maintenance, transportation, occupational health and safety, environment: Toronto, Canada, Pergamon Press, p. 29-40.

Orocobre, 2010, Olaroz lithium project: Orocobre Web page accessed January 3, 2010, at http://www.orocobre.com.au/Projects_Olaroz.htm.

Orris, G.J., 1997, Two methodologies for assessing boron in Quaternary salar and lacustrine settings: Tucson, Ariz., University of Arizona, Ph.D. dissertation, 281 p.

Papke, K.G., 1976, Evaporites and brines in Nevada playas: Nevada Bureau of Mines and Geology Bulletin 87, 35 p.

Pavlovic, P., and Fowler, J., 2004, Evaluation of the potential of Salar del Rincon brine deposit as a source of lithium, potash, boron and other mineral resources: Melbourne, Australia, Admiralty Resources NL, 32 p., accessed online October 5, 2011, at http://www.ady.com.au/images/pdfs/asx_annoucement/a5e00132373a7031000fd987a3c9f87b.pdf.) Pueyo, J.J., Chong, G., and Jensen, A., 2001, Neogene evaporites in desert volcanic environmentsAtacama Desert, northern Chile: Sedimentology, v. 48, p. 1141-1431. 
Risacher, F., and Fritz, B., 2009, Origin of salts and brine evolution of Bolivian and Chilean salars: Aquatic Geochemistry, v. 15, p. 123-157.

Roberts, T.L., 2008, Global potassium reserves and potassium fertilizer use, presentation to Global Nutrient Cycling Symposium: International Plant Nutrition Institute Web page, accessed October 6, 2008, at http://www.ipni.net/ipniweb/portal.nsf/0/9c5cff1af71db2ce852574e8004ecc00/\$FILE/Roberts\%20$\% 20 A S A \% 20$ Nutrient\%20Cycling\%20Symposium\%20Potash.pdf

Rodinia Lithium, 2011, Salar de Diablillos project: Toronto, Rodinia Lithium Web page, accessed March 11, 2011, at http://rodinialithium.com/projects/diabillos/.

Roskill Information Services, 1989, The economics of potash (2d ed.): London, Roskill Information Services Ltd., 121 p.

Singer, D.A., 1993, Basic concepts in three-part quantitative assessments of undiscovered mineral resources: Nonrenewable Resources, v. 2, no. 2, p. 69-81.

Singer, D.A., and Menzie, W.D., 2010, Quantitative mineral resource assessments-An integrated approach: New York, Oxford University Press, 219 p.

Smith, G.I., 1976, Origin of lithium and other components in the Searles Lake evaporites, California, in Vince, J.D., ed., Lithium resources and requirements by the year 2000: U.S. Geological Survey Professional Paper 1005, p. 92-103.

Sorentino, C.M.R., 2004, Report of an independent technical review and valuation of the Salar del Rincón asset and opinion on the market value of Admiralty Resources NL: Melbourne, Victoria, Australia, Admiralty Resources, $15 \mathrm{p}$.

Tripp, B.T., 2001, Industrial rock and mineral resources and developments in Utah, in Bon, R.L., Riordan, R.F., Tripp, B.T., and Krukowski, S.T., eds., Proceedings of the 35th Forum on the Geology of Industrial Minerals-The Intermountain West Forum 1999: Utah Geological Survey Miscellaneous Publication 01-2, p. 79-92.

Tse, P.-K., 2009, The mineral industry of China [advance release] in Area reports-International: U.S. Geological Survey Minerals Yearbook 2007, p. 9.1-9.24, accessed February 17, 2010, at http://minerals.usgs.gov/minerals/pubs/country/.

Van Kauwenbergh, S.J., 2006, Fertilizer raw material resources of Africa: Muscle Shoals, Alaska, International Fertilizer Development Center, 435 p.

Wang, M., Liu, C., Jiao, P., and Yang, Z., 2005, Minerogenic theory of the superlarge Lop Nur potash deposit, Xinjiang, China: Acta Geologica Sinica, v. 79, no. 1, p. 53-65.

Warren, J., 1999, Evaporites_-Their evolution and economics: Malden, Mass., Blackwell Science, $438 \mathrm{p}$.

Yu, G., Harrison, S.P., and Xue, B., 2001, Lake status records from China-Data base documentation: Max-Planck-Institut für Biogeochemie Technical Report 4, 243 p.

Yuan, J., Cai, K., Tao, W., Wang, Q., Shuai, K., Peng, S., Li, R., Wei, D., and Zhang, Y., 1996, Salt deposits of China, in The Editorial Committee of The Mineral Deposits of China, ed., Mineral deposits of China, Volume 4: Beijing, China, Geological Publishing House, p. 168-234.

Zheng, X., 1984, Distribution characteristics of boron and lithium in brine of Zhacang Caka salt lake, Xizang (Tibet), China: Chinese Journal of Ocenology and Limnology, v. 2, no. 2, p. 218-227. 
Table 1. Known potash-bearing brine deposits in continental closed basins. For size comparison purposes, a 1 billion metric ton stratabound potash deposit on average would contain less than $250 \mathrm{Mt}$ of $\mathrm{K} 2 \mathrm{O}$ (400 Mt KCl, $210 \mathrm{Mt} \mathrm{K}$ ).

[B, boron; est, estimated; H2S, hydrogen sulfide; HAL, salt (halite); inf, inferred; K, potassium; K2O, potassium oxide; KCl, potassium chloride; LI, lithium; MG, magnesium; Mt, millions metric tons; NACO, sodium carbonate (trona); NASO, sodium sulfate; res, resource; rsv, reserve]

\begin{tabular}{|c|c|c|c|c|c|c|}
\hline Deposit & Country & $\begin{array}{l}\text { Commodities } \\
\text { Present }\end{array}$ & $\begin{array}{l}\text { Development } \\
\text { Status }\end{array}$ & $\underset{(\mathrm{mg} / \mathrm{l})}{\mathrm{K}_{2} \mathrm{O}}$ & $\begin{array}{c}\text { Reported } \\
\text { Reserves/Resources }\end{array}$ & References \\
\hline Cauchari, Salar de & $\begin{array}{l}\text { Argentin } \\
\mathrm{a}\end{array}$ & LI K & exploration & $\begin{array}{c}3,480 \text { to } \\
8,328\end{array}$ & $\begin{array}{l}\text { inf in situ res, north central } \\
\text { area-7.7 Mt K (2010) }\end{array}$ & $\begin{array}{l}\text { Houston (2010a), King } \\
(2010)\end{array}$ \\
\hline Centenario, Salar de & $\begin{array}{l}\text { Argentin } \\
\mathrm{a}\end{array}$ & LI K & exploration & up to 10,000 & & $\begin{array}{l}\text { Mining Exploration } \\
\text { News (2011) }\end{array}$ \\
\hline Diablillos, Salar de & $\begin{array}{l}\text { Argentin } \\
\text { a }\end{array}$ & LI K B & exploration & $\begin{array}{l}5,270 \text { to } \\
6,600\end{array}$ & inf res-10.4 Mt K (2011) & $\begin{array}{l}\text { Rodinia Lithium (2011), } \\
\text { Larrondo and others } \\
\text { (2011) }\end{array}$ \\
\hline $\begin{array}{l}\text { Hombre Muerto, } \\
\text { Salar del }\end{array}$ & $\begin{array}{l}\text { Argentin } \\
\mathrm{a}\end{array}$ & LI B L MG & occurrence & $7,400^{1}$ & est rsv-30 Mt (1996) & Garrett (1996) \\
\hline Olaroz, Salar de & $\begin{array}{l}\text { Argentin } \\
\text { a }\end{array}$ & LI K B & exploration & 8,000 & inf res- $4.4 \mathrm{Mt} \mathrm{KCl}$ & $\begin{array}{l}\text { Orocobre }(2010), \\
\text { Houston and Ehren } \\
(2010), \text { King }(2010)\end{array}$ \\
\hline Rincón, Salar de & $\begin{array}{l}\text { Argentin } \\
\text { a }\end{array}$ & HAL LI K B MG & exploration & $7,490^{1}$ & $\inf -9.02 \mathrm{~K}(2011)$ & $\begin{array}{l}\text { Mining Exploration } \\
\text { News (2011), Sorentino } \\
(2004)\end{array}$ \\
\hline Salinas Grandes & $\begin{array}{l}\text { Argentin } \\
\text { a }\end{array}$ & LI K B & exploration & 11,200 & & Houston (2010b) \\
\hline $\begin{array}{l}\text { Pastos Grandes, } \\
\text { Lagunas }\end{array}$ & Bolivia & LI K B & exploration & 14,200 & & $\begin{array}{l}\text { New World Resource } \\
\text { Corp. (2008) }\end{array}$ \\
\hline Uyuni, Salar de & Bolivia & HAL LI K B & occurrence & $8,640^{1}$ & & $\begin{array}{l}\text { Ballivían and Risacher } \\
\text { (1981) }\end{array}$ \\
\hline Atacama, Salar de & Chile & LI K & producer & $22,200^{1}$ & $>120 \mathrm{Mt} \mathrm{KCl}$ & $\begin{array}{l}\text { Roberts (2008), Pueyo } \\
\text { and others (2001) }\end{array}$ \\
\hline Bellavista, Salar de & Chile & HAL K & $\begin{array}{l}\text { small past } \\
\text { production }\end{array}$ & & & Ericksen (1963) \\
\hline Maricunga, Salar de & Chile & LI K B & exploration & $\begin{array}{l}6,000 \text { to } \\
>18,000\end{array}$ & & $\begin{array}{l}\text { Li3 Energy (2011), } \\
\text { Hains (2011) }\end{array}$ \\
\hline $\begin{array}{l}\text { Da Chaidam Salt } \\
\text { Lake }\end{array}$ & China & $\begin{array}{l}\text { LI K B MG } \\
\text { NASO }\end{array}$ & production & $25,700^{2}$ & & $\begin{array}{l}\text { Yu and others (2001), } \\
\text { Gao and others (1993) }\end{array}$ \\
\hline Lop Nur & China & HAL K & producer & $\begin{array}{c}5,400 \text { to } \\
11,000\end{array}$ & res $\longrightarrow 250 \mathrm{Mt}$ "potash" & $\begin{array}{l}\text { Tse (2009), Wang and } \\
\text { others }(2005)\end{array}$ \\
\hline
\end{tabular}




\begin{tabular}{|c|c|c|c|c|c|c|}
\hline $\begin{array}{l}\text { Qarhan Salt Plain } \\
\text { (Dabusun, others) }\end{array}$ & China & HAL K LI B MG & producer & $\begin{array}{l}14,400 \text { to } \\
20,900^{2}\end{array}$ & $440 \mathrm{Mt} \mathrm{KCl} \mathrm{(1968)}$ & $\begin{array}{l}\text { Yuan and others (1996), } \\
\text { Duan and } \mathrm{Hu}(2001) \\
\text { Geological Survey and }\end{array}$ \\
\hline Khour & Iran & K HAL MG & occurrence & 1,450 to 4000 & & $\begin{array}{l}\text { Mineral Exploration of } \\
\text { Iran (2007); }\end{array}$ \\
\hline Rezayeh, Lake & Iran & $\mathrm{K}$ & occurrence & $1,100^{2}$ & $60 \mathrm{Mt} \mathrm{K}_{2} \mathrm{O}(1983)^{4}$ & Notholt (1983) \\
\hline Dead Sea & $\begin{array}{l}\text { Israel, } \\
\text { Jordan }\end{array}$ & $\mathrm{K} \mathrm{MG}$ & producer & $\begin{array}{l}7,200 \text { to } \\
9,000^{2}\end{array}$ & $2,050 \mathrm{Mt} \mathrm{KCl}(1983)^{4}$ & Garrett (1996) \\
\hline Edri & Libya & HAL K S & occurrence & $3,050^{2}$ & & Goudarzi (1982) \\
\hline Marada & Libya & HAL K MG & $\begin{array}{l}\text { small past } \\
\text { production }\end{array}$ & $22,600^{2}$ & & $\begin{array}{l}\text { Goudarzi (1982), Van } \\
\text { Kauwenbergh (2006), } \\
\text { Notholt (1983) }\end{array}$ \\
\hline Bayovar & Peru & $\mathrm{K} \mathrm{MG}$ & exploration & up to $4,900^{2}$ & $19 \mathrm{Mt} \mathrm{KCl}(1983)^{4}$ & $\begin{array}{l}\text { Industrial Minerals } \\
\text { (2010), GrowMax Agri } \\
\text { Corp. (2011), Americas } \\
\text { Petrogas (2010) }\end{array}$ \\
\hline Chott el Djerid & Tunisia & HAL MG K & occurrence & $\begin{array}{l}1,830 \text { to } \\
5,200^{2}\end{array}$ & inf rsv-19 $\mathrm{Mt} \mathrm{K}_{2} \mathrm{O}(1983)^{4}$ & $\begin{array}{l}\text { Garrett (1996); Notholt } \\
\text { (1983) }\end{array}$ \\
\hline Tuzgolu (Salt Lake) & Turkey & HAL K MG & occurrence & $\begin{array}{l}8,900 \text { to } \\
46,000\end{array}$ & & Kilic and Kilic (2005) \\
\hline Lake Katwe & Uganda & HAL K H2S & $\begin{array}{l}\text { small } \\
\text { production } \\
(1991)\end{array}$ & 30,500 & & Kisitu (1991) \\
\hline Bonneville $^{3}$ & $\begin{array}{l}\text { United } \\
\text { States }\end{array}$ & $\begin{array}{l}\text { HAL K MG LI } \\
\text { NASO }\end{array}$ & $\begin{array}{l}\text { production } \\
(2001)\end{array}$ & $\begin{array}{c}2,400^{2} \text { to } \\
7,800^{1}\end{array}$ & & $\begin{array}{l}\text { Gwynn }(1996,2001) \text {, } \\
\text { Tripp (2001), Warren } \\
(1999)\end{array}$ \\
\hline $\begin{array}{l}\text { Clayton Valley } \\
\text { (Silver Peak) }\end{array}$ & $\begin{array}{l}\text { United } \\
\text { States }\end{array}$ & LI K & occurrence & $\begin{array}{l}4,800^{2} \text { to } \\
6,360^{1}\end{array}$ & est rsv-30 Mt (1996) & $\begin{array}{l}\text { Garrett (1996), Papke } \\
\text { (1976) } \\
\text { Smith (1976), British }\end{array}$ \\
\hline Searles Lake & $\begin{array}{l}\text { United } \\
\text { States }\end{array}$ & NACO LI K & $\begin{array}{l}\text { past } \\
\text { production }\end{array}$ & $\begin{array}{l}17,900 \text { to } \\
31,000^{2}\end{array}$ & & $\begin{array}{l}\text { Sulphur Corporation } \\
\text { (1984), Roskill } \\
\text { Information Services } \\
(1989)\end{array}$ \\
\hline
\end{tabular}

\footnotetext{
from Pavlovic and Fowler (2004); values not necessarily representative of potential production grades.

2 from Garrett (1996); values not necessarily representative of potential production grades.

3 includes entire paleo-Lake Bonneville extent, including Great Salt Lake, Great Salt Lake desert, Bonneville Salt Flats, and Sevier Desert area.

4 from Notholt (1983)
} 

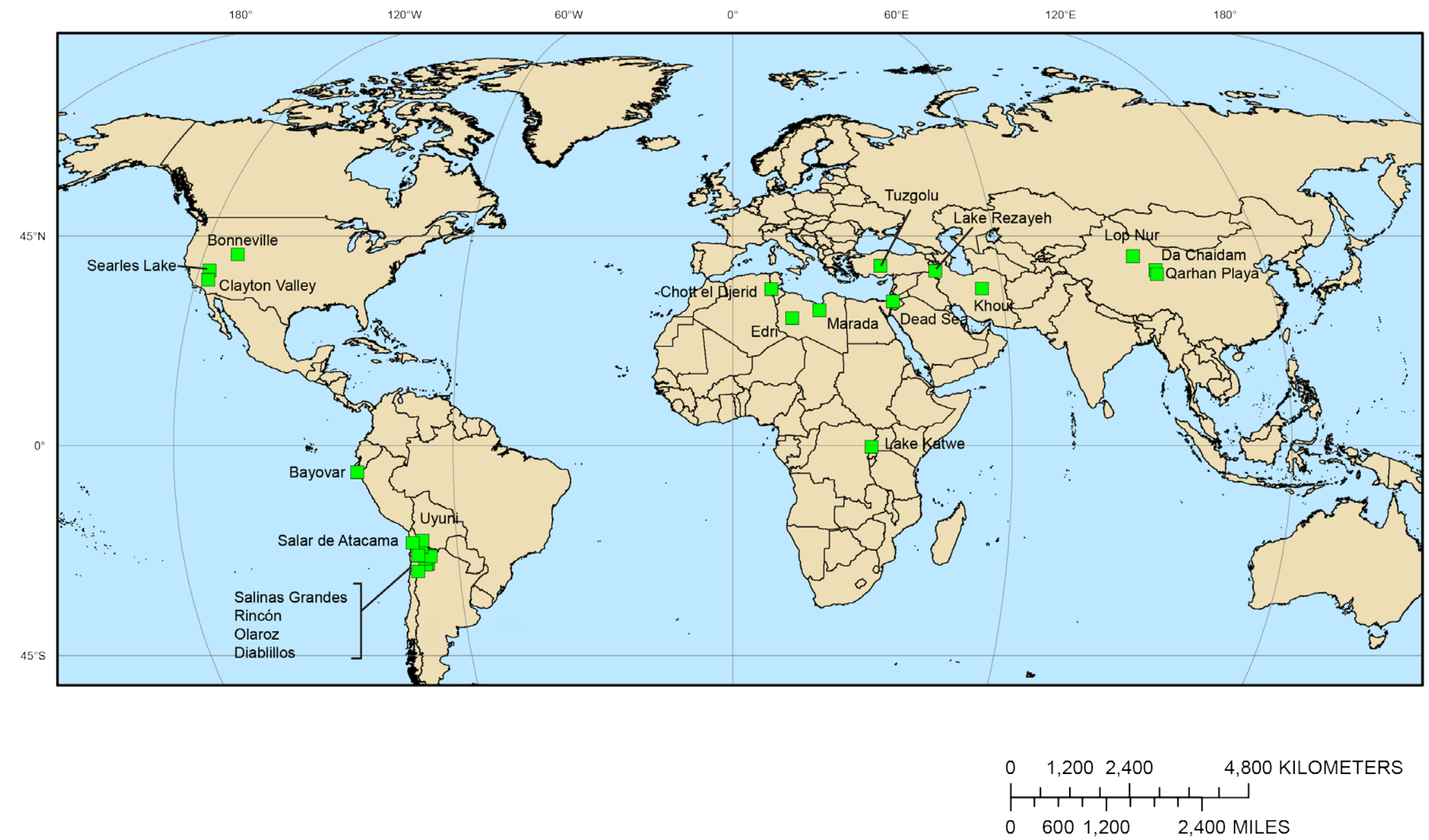

Figure 1. Distribution of closed-basin potash-bearing brine deposits listed in table 1; deposits are shown as green squares. 


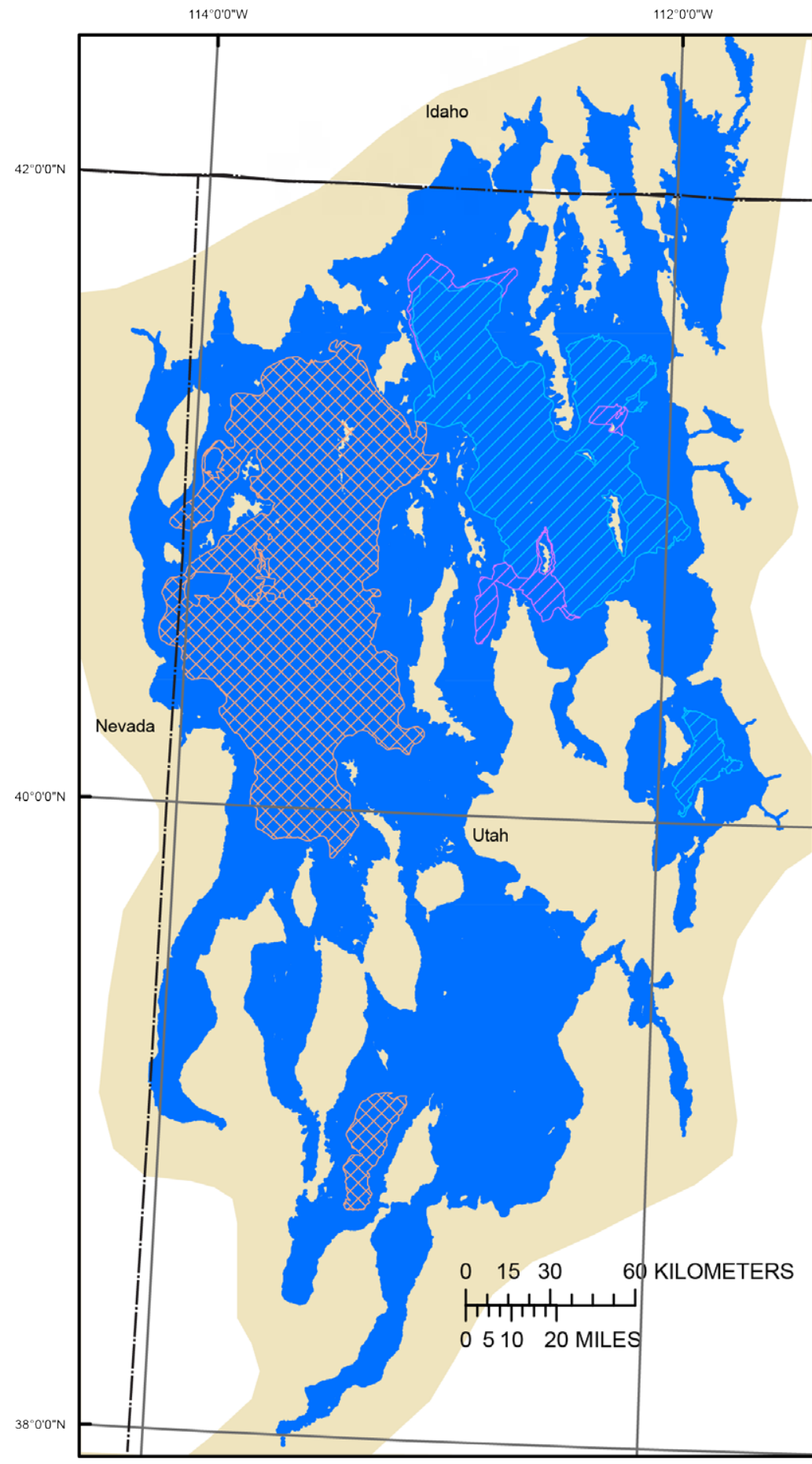

\section{EXPLANATION}

Extent of Lake Bonneville

Lake

Intermittent Lake

Dry Lake

Pre-Pleistocene rocks

Figure 2. Possible extent of area underlain by Lake Bonneville potash-bearing brines, including the Great Salt Lake, the Great Salt Lake Desert, and Sevier Lake. The extent of Lake Bonneville was determined by using the Digital Elevation Model data, and everything above 5090 feet is excluded. This is a good match with the map shown in Currey and others, 1984. 


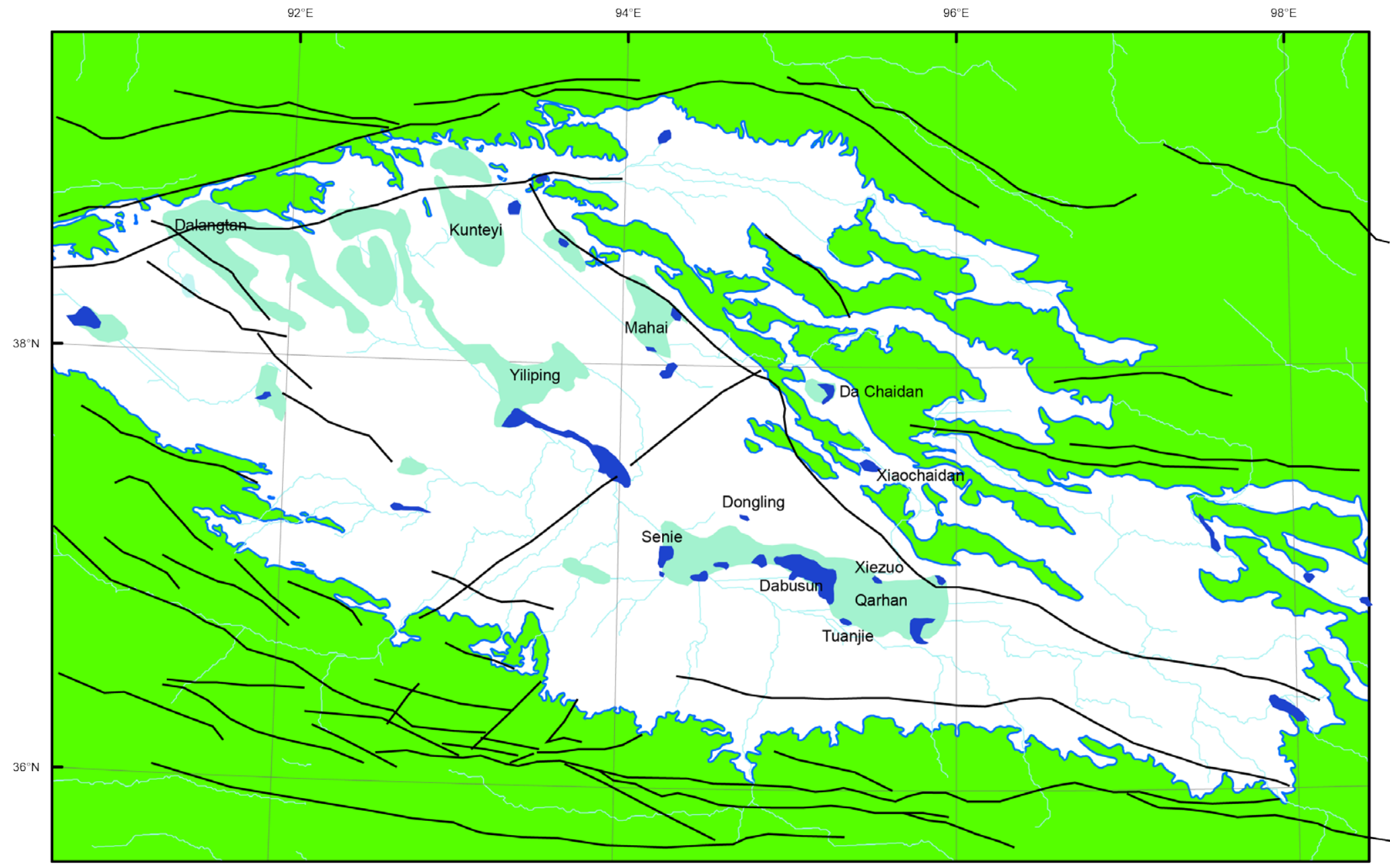

EXPLANATION

$\square$ Quaternary Playas

$\square$ Undifferentiated Pliocene to

Quaternary sediments

Pre-Cenozoic rocks

\section{$02550 \quad 100$ KILOMETERS}

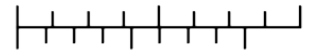

o $12.525 \quad 50$ MILES

Figure 3. Sketch map of Qaidam Basin, China, showing playas and salt lakes. The Qarhan Salt Plain (playa), where most of the current production occurs, is shown in the lower center of the figure. 